\title{
Something of a Girls Studies Reader?
}

\author{
Claudia Mitchell
}

\section{$\cos 80$}

Sometimes the evolution of an open call issue of Girlhood Studies results in something of a girls studies reader unto itself. Since this issue is packed full of criss-crossing themes based on work in several countries-Canada, Iceland, India and the US - there is just no room for editorial commentary. In its inclusion of works on intersectional feminisms and feminist and Indigenous-led critique to school-based and intergenerational interventions and the power of the visual, this issue is something of such a reader.

We open it with Halle Singh's "Method-ological Mapping of Girlhood Studies: The Academic Landscapes of Girlhood" in which she reports on a "mapping project of the methods used in articles in Girlhood Studies . . . published . . . from June 2008 to December 2020.”

In "The End of the Tunnel: Girls' Marked Bodies in the Canadian Transcarceral Pipeline," Sandrina de Finney and Mandeep Kaur Mucina discuss the "social service interventions embedded in the gendered genocidal logics of colonial ideologies" that are enacted on "Indigenous girls and BIPOC refugee girls in Canada."

Shara Crookston and Monica Klonowski, in "Intersectional Feminism and Social Justice in Teen Vogue" argue that this teen magazine, in evolving "to encompass aspects of intersectional feminist activism that is particularly evident in the 2017 "Voices" section of the magazine" . . challenges previous research on such periodicals.

In "Female Pleasure and the Gender Politics of 'Girliyapa" Shailendra Kumar examines "the discursive portrayals of gendered experience and subject positions [in] an online entertainment channel ... for female-oriented content in India." Its focus on "marital rape, color prejudice, and workplace sexism" for example, interrogates what counts as girl power here.

"When Princesses Become Dragons: Critical Literacy, Damsel, and Confronting Rape Culture in English Classrooms" by Shelby Boehm, 
Kathleen Colantonio-Yurko, Kathleen Olmstead, and Henry "Cody" Miller focuses on "offer[ing] curricular suggestions for teaching Elana K. Arnold's young adult title Damsel, a subverted fairytale rewrite, using a critical literacy framework."

In "The Discourse of Drama: Regulating Girls in an Icelandic School," Bergljót Thrastardóttir, Steinunn Helga Lárusdóttir, and Ingólfur Ásgeir Jóhannesson "consider how girls are positioned in school by . . the discourse of drama" and how they, "despite living in what is seen to be a country that upholds gender equality, are silenced through this discourse."

We conclude this section with "Physical Culture Drills and Alberta Girls Stepping Together Across Time" by Heather Fitzsimmons Frey and Jenna Kerekes, who, in "using performance-based historiography as a methodology," show how "participants explored what embodying physical culture movement vocabulary could reveal about archives, past girls, and themselves."

We include two photo essays. In "Breaching Flowery Borders" Leslie Midkiff DeBauch looks at "early twentieth century girls scrapbooking their lives" while in their photo essay, "Beholding Ourselves: Black Girls as Creators, Subjects, and Witnesses," Erin Stephens and Jamaica Gilmer demonstrate how "the arts and a supportive community . . combine to enable Black girls to become "agents of change."

We end this issue with two book reviews, Amélie Lemieux's "Beyond Representation: Technofeminisms and the Promise of Computing for Girls" on Kristine Blair's Technofeminist Storiographies: Women, Information Technology, and Cultural Representation (2019) and Thalia Thereza Assan's "What's a Girl to Do? The Pleasures and Pressures of the Girls' Night Out" based on Emily Nicholls's Negotiating Femininities in the Neoliberal NightTime Economy: Too Much of a Girl? (2019).

This issue is a feast of ideas, and we thank the contributors and reviewers. 